\title{
Digital Cashless Payment Readiness Model on MSMEs Using Technological-Organization-Environtment (TOE) Framework: Study on MSME Users Gopay and Ovocash)
}

\author{
Novita Ekasari ${ }^{1{ }^{*}}$ Rosmeli Rosmeli ${ }^{2}$, Rista Aldilla Syafri ${ }^{3}$ \\ ${ }^{123}$ Universitas Jambi, Indonesia \\ *Corresponding author. Email: Ekasari.novita01@gmail.com
}

\begin{abstract}
The success of a good business is determined by a strategy that is able to compete with its competitors, one of which is by using a non-cash payment system (digital) so as to provide convenience for consumers to make payments anywhere and anytime there both for online and offline sales. Non-cash payment methods have begun to be applied by businesses by starting to cooperate with the largest digital platforms in Indonesia, namely Go Pay and OVO cash. The purpose of this study is to see the readiness of micro, small and medium enterprises in using digital payment methods with a TOE (technology-organization-environment) approach and then see if they are ready to use digital payment seen from these 3 sides, this study represents samples from 5 cities in Sumatra Island namely Aceh, Medan, Jambi, Pekanbaru and Lampung.The study used a sample of respondents, who have collaborated with GoPay and OVOCash applications totaling 175 MSMEs. This research uses PLS and Path Analysis techniques with the SPSS test tool. The results showed that MSMEs in sumatra region can absorb the use of digital payments seen in terms of Technology with a percentage absorption of $75.8 \%$, Organization by $41.2 \%$ and Environment by $58.2 \%$. The conclusion of this study is that there is a readiness of businesses from 5 major cities in Sumatra to use digital payments Gopay and OVO cash that makes their business easier.
\end{abstract}

Keywords: Digital Cashless Payment, MSME, TOE Framework.

\section{INTRODUCTION}

Every company or business is required to create a good and integrated competitive strategy because competition is the key to the success or failure of a business, where consumer satisfaction will also depend on the business strategy used by a business. The increasing intensity of competition makes companies always pay attention to the needs and desires of consumers by providing a more satisfactory service than what their competitors already do. companies with high quality and competitiveness that are able to have many consumers. Technological changes and the social environment that occur in society also change the lifestyle of people where information technology such as internet and e-commerce with more efficient and practical means of communication has been able to change the way consumers live including the way of shopping.
Bank Indonesia stated that in 2018 Go Pay was able to register itself as the highest mobile payment platform with a percentage of $79.3 \%$, then OVO $58.4 \%$ [1]. In the use of transactions on MSMEs, Go Pay and OVO that have cooperated with Grabpay where GrabPay consumers now pay are replaced with OVO Cash. Therefore, this research is limited to two large vendors namely GoPay and OVO Cash. Although GoPay and OVO are easy to find in MSMEs but in their implementation some MSMEs still encounter confusion and difficulties especially for micro businesses and small businesses that still have difficulty in making Mobile Payment transactions because they have not mastered the technology or feel the need for extra time to make transactions with mobile payment. Based on preliminary surveys, most consumers prepare cash to make payments to micro-businesses such as food stalls and small exchanges. 
The purpose of this research is to get an idea of the level of readiness of MSMEs in Sumatra island where the level of readiness may differ from MSMEs located in Java island which is notabene in a more modern environment. Some previous researchers have conducted studies with the same variables but with narrower research scope and fewer objects. This research was conducted with a broader scope of research namely MSMEs located in the island territory of Sumatra so that they can get an idea of the level of readiness of MSMEs in Sumatra Island where the level of readiness may differ from MSMEs located in Java island which is notabene in a more modern environment.

\section{METHODS}

\subsection{Data Source}

Based on the source, the data can be divided into two, namely Primary Data and Secondary Data : a. Primary data is data created by researchers for the special purpose of solving the problems that are being handled. The data were collected by researcher directly from the first source or object where research is conducted.

b. Secondary data is data that has been collected for purposes other than to solve the problem at hand. This data can be found quickly. In this study, the secondary data source is literature, articles, journals and websites on the internet with regard to the research conducted.

\subsection{Operationalization of Research Variables}

The operational definition describes a particular method that is used by researchers to operationalize the construct, thus allowing other researchers to conduct repeatability of measurements in the same way or trying to distribute construct a better measurement. In this study, the operational definition outlined in the following table:

Table 1: Variable Operational Research

\begin{tabular}{|c|c|c|c|c|}
\hline Variable & Sub variables & Code & Indicators & $\begin{array}{c}\text { Measuring } \\
\text { Scale }\end{array}$ \\
\hline \multirow[t]{3}{*}{ Technology } & $\begin{array}{l}\text { Relative } \\
\text { Advantage }\end{array}$ & $\begin{array}{l}\text { T01 } \\
\text { T02 } \\
\text { T03 } \\
\text { T04 }\end{array}$ & $\begin{array}{ll} & \text { Advantages of using } \\
& \text { systems/applications } \\
\text { - } & \text { Excellence in maintenance } \\
\text { - } & \text { Excellence in time } \\
\text { - } & \text { Excellence in Services } \\
\end{array}$ & Ordinal \\
\hline & Compability & $\begin{array}{l}\text { T05 } \\
\text { T06 } \\
\text { T07 } \\
\text { T08 }\end{array}$ & $\begin{array}{l}\text { - } \\
\text { - } \\
\text { - } \\
\text { - } \\
\text { - } \\
\text { In accordinsing tont with business needs } \\
\text { the organization/business adopted. }\end{array}$ & Ordinal \\
\hline & Complexity & $\begin{array}{l}\text { T09 } \\
\text { T10 } \\
\text { T11 } \\
\text { T12 }\end{array}$ & $\begin{array}{l}\text { Ease of using the system } \\
\text { - } \\
\text { - } \\
\text { The Flow of system is easy to } \\
\text { understand } \\
\text { No difficulty at all in using the } \\
\text { system }\end{array}$ & \\
\hline \multirow[t]{3}{*}{ Organization } & $\begin{array}{l}\text { Organizational } \\
\text { Competency }\end{array}$ & $\begin{array}{l}\mathrm{O} 1 \\
\mathrm{O} 2 \\
\mathrm{O} 3 \\
\mathrm{O} 4\end{array}$ & $\begin{array}{ll}- & \text { Application of IT in business } \\
\text { - } & \text { Organizational ability to adapt } \\
\text { - } & \text { Teamwork } \\
\text { - } & \text { Management efforts for } \\
& \text { organizations } \\
\end{array}$ & \\
\hline & $\begin{array}{l}\text { Management } \\
\text { Support }\end{array}$ & $\begin{array}{l}\mathrm{O} 5 \\
\mathrm{O} 6 \\
\mathrm{O} 7 \\
\mathrm{O} 8\end{array}$ & $\begin{array}{ll}- & \text { Reliable owner (top Management) } \\
- & \text { Good leadership } \\
- & \text { Good business management } \\
- & \text { How to troubleshoot issues in your } \\
\text { organization }\end{array}$ & \\
\hline & $\begin{array}{l}\text { Training and } \\
\text { Education }\end{array}$ & $\begin{array}{l}\text { O9 } \\
\text { O10 } \\
\text { O11 }\end{array}$ & $\begin{array}{l}\text { Training to improve user } \\
\text { knowledge } \\
\text { Organizations initiating employee } \\
\text { training and learning } \\
\text { - Continuous understanding for users } \\
\text { Trainings makes user more } \\
\text { confident. }\end{array}$ & \\
\hline
\end{tabular}




\begin{tabular}{|c|c|c|c|c|}
\hline Environment & $\begin{array}{l}\text { Competitive } \\
\text { Pressure }\end{array}$ & $\begin{array}{l}\text { E1 } \\
\text { E2 } \\
\text { E3 } \\
\text { E4 }\end{array}$ & $\begin{array}{ll} & \text { Competitiveness with competitors } \\
\text { - } & \text { Advantages for businesses } \\
\text { - } & \text { Attract more customers } \\
\text { - } & \text { Higher selling value }\end{array}$ & Ordinal \\
\hline & $\begin{array}{l}\text { Trading Patner } \\
\text { Support }\end{array}$ & $\begin{array}{l}\text { E5 } \\
\text { E6 } \\
\text { E7 } \\
\text { E8 }\end{array}$ & $\begin{array}{ll}\text { - } & \text { System tested } \\
\text { - } & \text { Guaranteed in security } \\
\text { - } & \text { Insurance guarantee } \\
\text { - } & \text { Trading Patner Support }\end{array}$ & \\
\hline Adoption & $\begin{array}{l}\text { Adoption } \\
\text { Intention }\end{array}$ & $\begin{array}{l}\text { A1 } \\
\text { A2 } \\
\text { A3 }\end{array}$ & $\begin{array}{ll}\text { - } & \text { Desire to use technology } \\
\text { - } & \text { Interest in the development of } \\
\text { businesses using technology } \\
\text { - } & \begin{array}{l}\text { Suggest using technology to } \\
\text { business associates }\end{array}\end{array}$ & \\
\hline
\end{tabular}

\subsection{Population and Sample}

In this study, the population was a business consumer (MSME) of GoPay and OVO Cash application users spread across five major cities in Sumatra, namely Aceh, Medan, Jambi, Pekanbaru and Lampung amounting to 259,701 MSMEs. This population does not represent the number of MSMEs who already use Gopay and OVO Cash applications because the data is not available definitively, so for the population of Gopay and OVO Cash users themselves who each year increase cannot be known the exact number. Based on the information, the sampling in this study used the formula Hair that if the sample size is too large, then the method becomes so sensitive that it is difficult to get goodness of fit so it is recommended that the minimum sample size is 5-10 observations for each observed parameter. Thus, in this study jumalah parameters are as many as 35 items, so jumalah the recommended sample is $35 \times 5=175$ MSMEs. The technique of sampling is simple random sampling that is the technique to get samples directly done in the sampling unit.

\subsection{Data Analysis Method}

This research uses the Partial Least Square (PLS) analysis method which is a multivariate statistical technique that can handle many variable responses as well as variable explanatory at once. Partial Least Square is a technique that can handle many variables even if there is multicolineity between these variables. To test the validity and reability of the feeding indicator is used outer model. Path analysis is used to see how the TOE Framework variable affects Adoption Intention.

\section{RESULT}

Respondents in this study consisted of several characteristics: characteristics of respondents based on gender, age, marital status, business domicile, business type, type of application and length of use of the application. For more details can be seen in the following tables.

Table 2. Distribution Characteristics of Respondents Table Research

\begin{tabular}{|c|c|c|c|}
\hline \multirow{2}{*}{ Sex } & Male & 79 & $44,89 \%$ \\
\hline & Female & 97 & $55,11 \%$ \\
\hline \multicolumn{2}{|c|}{ Total } & 176 & \\
\hline \multirow{3}{*}{ Age } & $20-30$ years old & 112 & $63,64 \%$ \\
\hline & $31-40$ years old & 50 & $28,41 \%$ \\
\hline & $>40$ years old & 14 & $7,95 \%$ \\
\hline \multicolumn{2}{|c|}{ Total } & 176 & \\
\hline \multirow{2}{*}{ Marital Status } & Unmarried & 87 & $49,43 \%$ \\
\hline & Married & 89 & $50,57 \%$ \\
\hline \multicolumn{2}{|c|}{ Total } & 176 & \\
\hline \multirow{6}{*}{ Business domicile } & Aceh & 12 & $6,82 \%$ \\
\hline & Medan & 17 & $9,66 \%$ \\
\hline & Pekanbaru & 17 & $9,66 \%$ \\
\hline & Palembang & 10 & $5,68 \%$ \\
\hline & Jambi & 113 & $64,20 \%$ \\
\hline & Lampung & 7 & $3,98 \%$ \\
\hline \multicolumn{2}{|c|}{ Total } & 176 & \\
\hline \multirow{4}{*}{ Business Type } & Culinary & 96 & $54,55 \%$ \\
\hline & Fashion & 29 & $16,48 \%$ \\
\hline & Medical supplies & 10 & $5,68 \%$ \\
\hline & cosmetics & 9 & $5,11 \%$ \\
\hline
\end{tabular}




\begin{tabular}{|c|c|c|c|}
\hline & Electronic & 7 & $3,98 \%$ \\
\hline & Services & 16 & $9,09 \%$ \\
\hline & Others & 9 & $5,11 \%$ \\
\hline \multicolumn{2}{|c|}{ Total } & 176 & \\
\hline \multirow{3}{*}{ Applications used } & GoPay & 46 & $26,14 \%$ \\
\hline & OVOCASH & 67 & $38,07 \%$ \\
\hline & $\begin{array}{l}\text { GoPay dan } \\
\text { OVOCASH }\end{array}$ & 63 & $35,80 \%$ \\
\hline \multicolumn{2}{|c|}{ Total } & 176 & \\
\hline \multirow{3}{*}{$\begin{array}{l}\text { Length of } \\
\text { cooperation }\end{array}$} & $<1$ Year & 88 & $50,00 \%$ \\
\hline & $1-3$ years & 82 & $46,59 \%$ \\
\hline & $>3$ years & 6 & $3,41 \%$ \\
\hline \multicolumn{2}{|c|}{ Total } & 176 & \\
\hline
\end{tabular}

Based on the results of this study, the following are models obtained from the calculation results using SmartPLS:

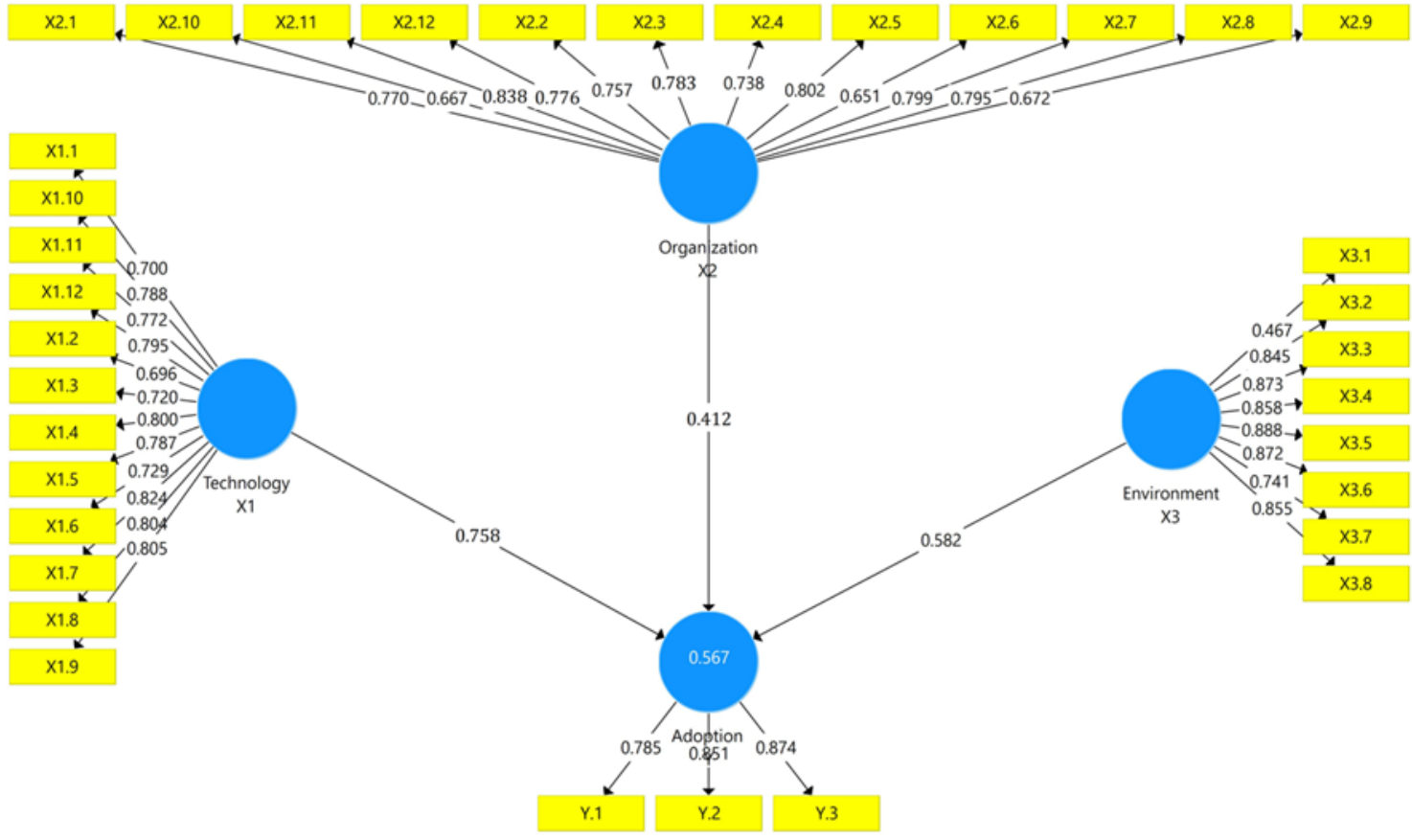

The initial measurement is calculated by measuring the loading factor result, which if the score is greater than 0.6 then it is considered significant. The results of loading factor measurement can be seen as follows:

Table 3. Outer Loading Factors

\begin{tabular}{|l|l|l|l|r|}
\hline & $\begin{array}{c}\text { Adoption } \\
\text { (Y) }\end{array}$ & $\begin{array}{c}\text { Environmen } \\
\mathbf{t}(\mathbf{X 3})\end{array}$ & $\begin{array}{c}\text { Organizatio } \\
\mathbf{n} \_(\mathbf{X 1})\end{array}$ & $\begin{array}{c}\text { Technology } \\
\text { (Y) }\end{array}$ \\
\hline X1.1 & & & & 0.700 \\
\hline X1.10 & & & & 0.788 \\
\hline X1.11 & & & & 0.772 \\
\hline X1.12 & & & & 0.795 \\
\hline X1.3 & & & & 0.720 \\
\hline X1.4 & & & & 0.800 \\
\hline X1.5 & & & & 0.787 \\
\hline X1.6 & & & & 0.729 \\
\hline X1.7 & & & & 0.824 \\
\hline X1.8 & & & & 0.804 \\
\hline
\end{tabular}




\begin{tabular}{|c|c|c|c|c|}
\hline X1.9 & & & & 0.805 \\
\hline $\mathrm{X} 2.1$ & & & 0.770 & \\
\hline $\mathrm{X} 2.11$ & & & 0.838 & \\
\hline $\mathrm{X} 2.12$ & & & 0.776 & \\
\hline $\mathrm{X} 2.2$ & & & 0.757 & \\
\hline $\mathrm{X} 2.3$ & & & 0.783 & \\
\hline $\mathrm{X} 2.4$ & & & 0.738 & \\
\hline $\mathrm{X} 2.5$ & & & 0.802 & \\
\hline $\mathrm{X} 2.7$ & & & 0.799 & \\
\hline $\mathrm{X} 2.8$ & & & 0.795 & \\
\hline X3.2 & & 0.845 & & \\
\hline X3.3 & & 0.873 & & \\
\hline X3.4 & & 0.858 & & \\
\hline X3.5 & & 0.888 & & \\
\hline X3.6 & & 0.872 & & \\
\hline X3.7 & & 0.741 & & \\
\hline X3.8 & & 0.855 & & \\
\hline Y.1 & 0.785 & & & \\
\hline Y.2 & 0.851 & & & \\
\hline Y.3 & 0.874 & & & \\
\hline
\end{tabular}

Based on the table above, in performing the initial analysis data there are loading factor values on indicators
$\mathrm{X} 1.2, \mathrm{X} 2.10, \mathrm{X} 2.6, \mathrm{X} 2.9$ and X3.1 smaller than 0.6 then all five indicators are not included in the model.

Table 4. Construct Reliability and Validity

\begin{tabular}{|l|c|c|c|c|}
\hline & $\begin{array}{c}\text { Cronbach's } \\
\text { Alpha }\end{array}$ & rho_A & $\begin{array}{c}\text { Composite } \\
\text { Reliability }\end{array}$ & $\begin{array}{c}\text { Average Variance } \\
\text { Extracted (AVE) }\end{array}$ \\
\hline Adoption_Y & 0,790 & 0,819 & 0,876 & 0,702 \\
\hline Environment_X3 & 0,921 & 0,939 & 0,937 & 0,657 \\
\hline Organization_X2 & 0,916 & 0,933 & 0,926 & 0,512 \\
\hline Technology_X1 & 0,937 & 0,943 & 0,946 & 0,592 \\
\hline
\end{tabular}

The analysis of Cronbach's alpha in the table above shows that the score is more than 0.7 where the adoption variable is 0.790 , the environment is 0.921 , the organization is 0.916 and the technology is 0.937 . The results showed that the accuracy and reliability of all the variables in this study. Composite reliability with a score above 0.7 can then be declared to meet the reability. Based on the table above, it is seen that each variable in this study scored for composite reliability above 0.7 where the variable adoption variable is 0.876 , the environment is 0.937 , the organization is 0.926 and the technology is 0.946 . The results show that the variable as a whole is declared realibel. Validity measurement through Average Variance Extracted (AVE) where the score above 0.5 is declared to meet validity. Based on the table above it is seen that the overall variable score of
Average Variance Extracted (AVE) is above 0.5, where the adoption variable is 0.702 , the environment is 0.657 , the organization is 0.512 and the technology is 0.592 . The results show that the variable as a whole is declared to meet validity.

Table 5. R Square Value

\begin{tabular}{|l|r|r|}
\hline & R Square & R Square Adjusted \\
\hline Adoption_(Y) & 0,582 & 0,572 \\
\hline
\end{tabular}

The value of $\mathrm{R}$ Square in the table above obtained a value of 0.582 with a criterion of 0.3 means technology, organization and environmet are able to contribute or influence 0.582 on adoption. 
Table 6. Path Coefficients

\begin{tabular}{|l|r|r|r|r|r|l|}
\hline & $\begin{array}{c}\text { Original } \\
\text { Sample (O) }\end{array}$ & $\begin{array}{c}\text { Sample } \\
\text { Mean } \\
\text { SM) }\end{array}$ & $\begin{array}{c}\text { Standard } \\
\text { Deviation } \\
\text { (STDEV) }\end{array}$ & $\begin{array}{c}\text { T Statistics } \\
(\mid \mathbf{O} \text { (STDEV|) }\end{array}$ & \multicolumn{1}{|c|}{ P Values } & \multicolumn{1}{|c|}{ Result } \\
\hline $\begin{array}{l}\text { Environment_X3 -> } \\
\text { Adoption_(Y) }\end{array}$ & 0,582 & 0,572 & 0,161 & 6,865 & 0,000 & Accepted \\
\hline $\begin{array}{l}\text { Organization_X2 -> } \\
\text { Adoption_(Y) }\end{array}$ & 0,412 & 0,403 & 0,131 & 7,125 & 0,004 & Accepted \\
\hline $\begin{array}{l}\text { Technology_X1 -> } \\
\text { Adoption_(Y) }\end{array}$ & 0,758 & 0,698 & 0,164 & 5,983 & 0,000 & Accepted \\
\hline
\end{tabular}

The results of the environmental impact test on adoption amounted to 0.582 and $P$ value of 0.000 with a significant level of 0.05 . This indicates there is a positive influence of the environment on adoption, so if the environment increases by 1 (one) then adoption will increase by 0.582 . The results of the organization's influence test on adoption amounted to 0.412 and $P$ value of 0.004 with a significant level of 0.05 . This indicates that there is a positive influence on adoption, so if the environment increases by 1 (one) then adoption will increase by 0.412 .

The results of the technology influence test on adoption amounted to 0.758 and $\mathrm{P}$ value of 0.000 with a significant level of 0.05 . This indicates that there is a positive influence of technology on adoption, so if the environment increases by 1 (one) then adoption will increase by 0.758 .

\section{DISCUSSIONS}

\subsection{Technology has a positive effect on Adoption}

Based on the results of the analysis seen in the structural model, it can be seen that Techonogy has a positive and significant effect with a qualified loading factor value of more than 0.6 . It is also supported by a coefficient path result of 0.758 which means the hypothesis linking Technology Adoption has a positively significant influence. This influence is quite large when viewed from its value of $75.8 \%$ so it can be said that the readiness level of MSMEs is already good in adopting technology for their business. These results are similar to previous research that has stated that technology that is increasingly advanced and tends to be easy to use has a great influence for a person or group of people to adopt it thus simplifying their work [2]. Organization has a positive influence on Adoption

Structural model results show that organization has a positive influence on Adoption with loading factor value of more than 0.6. Meanwhile, the results of the path analysis show a coefficient number of 0.412 which means the hypothesis linking Organization Adoption has a positive and sigificant influence, with an influence of
0.412 or $41.2 \%$. The more prepared an organization is to use technology, the higher the intention of the organization's management in adopting technology. This is in line with the actions taken by top management in supporting and emphasizing their employees in using technology to facilitate and simplify their work, more often training is given to employees it will increase the motivation of employees to use technology. The results of this study support previous research that concluded that the Organization has an influence on Adoption [3] [4].

\subsection{Environment has a positive influence on Adoption}

Based on the results of the analysis on the Structural Model, variable Environment has a positive and significant influence with a loading factor value of more than 0.6 and a magnitude of influence of 0,582 or $58.2 \%$ which means that the Environment has a strong enough influence for an organization or business to absorb the use of technology through digital payment. The higher the technology used by the competitors, the stronger the desire to adopt technology for its business, especially if supported by the convenience provided by the business partner, namely the digital payment service provider. This opinion is in line with previous research conducted by Purwantini and Hakim [5] which concluded that variable Environment has an influence on Adoption Intention.

\section{CONCLUSION}

1. The results of the analysis show that MSMEs are ready to use GoPay and OVO as payment methods in their Businesses influenced by variable Technology- Organization Environment (TOE).

2. The most dominant factor influencing the intention of using Digital payment is Technology, then followed by Environment and Organization.

3. All variables (Technology-OrganizationEnvironment) have a positive and significant relationship to Adoption Intention so it can be said that all variables affect the intention of use 
(Adoption Intention) digital payment by MSMEs.

\section{RECOMMENDATIONS}

1. For the company of digital payment service providers namely GOJEK and OVO in order to be able to conduct mentoring education for MSMEs in order to be able to Go Digital because the organization factor gives the lowest influence on this research, meaning there is still a reluctance from MSMEs to literate technology due to lack of motivation.

2. For MSMEs who have implemented payment methods with GoPay and OVO in order to maintain and increase the use of technology in their business in order to have a wider market and high competitiveness so as not to lose to competitors.

3. For researchers in order to strengthen the weaknesses in this study, where the spread of questionnaires is disproportionate between regions so that it can be made in percentage so as to get a more proportionate and valid dissemination of respondents, pay attention to the editorial on the questionnaire to make it easier for respondents to understand and strengthen indicators so that no items are deleted or invalid, and expand the research area with more diverse digital payment service provider objects.

\section{ACKNOWLEDGMENT}

1. This research was funded by PNBP faculty of economics and business, University of Jambi in 2020 .

2. The Authors also would like to thank you to the Research and Community Service Institute of Jambi University (LPPM).

\section{REFERENCES}

[1] Techin Asia. (2019). Perkembangan Mobile Wallet di Indonesia. Jakarta. Retrieved from https://id.techinasia.com.

[2] J.L. Gibbs, \& K. Kraemer, (2004). A Cross-Country Investigation of The Determinants Of Scope ECommerce Use : An Institutional Approach.

[3] C. Martins, O. Tiago, \& A. Popovis, (2014). Understanding The Internet Banking Adoption. International Journal Of Information Managemenet, 34, 1-13.

[4] R. Rahayu, J. Day. (2015). Determinants Factors Of E-Commerce Adoption SMES's in Developing
Country: Evidence From Indonesia. Procedia Social and Behavioural Science, 195, 145-150.

[5] Purwantini \& A. Hakim, (2018). Anteseden dan Konsekuen Penggunaan Media Sosial Bagi UMKM: Analisis Perspektif Organisasi (september), 12-23 